\title{
Detection of salmonid alphavirus RNA in wild marine fish: implications for the origins of salmon pancreas disease in aquaculture
}

\author{
M. Snow*, J. Black, I. Matejusova, R. McIntosh, E. Baretto, I. S. Wallace, D. W. Bruno \\ Marine Scotland, Marine Laboratory, 375 Victoria Road, PO Box 101, Aberdeen AB11 9DB, UK
}

\begin{abstract}
Salmonid alphaviruses (SAVs), which include the aetiological agents of salmon pancreas disease (SPD) in farmed Atlantic salmon Salmo salar L. and sleeping disease (SD) in rainbow trout Oncorhynchus mykiss (Walbaum), are significant viral pathogens of European salmonid aquaculture. SAV is horizontally transmitted and the virus can survive for extended periods in seawater. A lack of convincing evidence for vertical transmission coupled to the fact that the SPD virus (SPDV) occurs in historically infected sites irrespective of fallow period duration suggests that a substantial reservoir of infection exists in the marine environment. We used a highly sensitive real-time PCR (qPCR) assay targeting a region of the SAV nsP1 gene to screen wild marine fish species for the presence of SAV in an attempt to identify such a potential reservoir. Screened fish species were caught in the vicinity of aquaculture activity in an area with a previous history of SAV infection (Shetland Isles, Scotland). SAV RNA was detected in internal organs (kidney and heart) from the flatfish species common dab Limanda limanda, long rough dab Hippoglossoides platessoides, and plaice Pleuronectes platessa. Based on these findings, sampling was extended to an area remote from aquaculture activity (Stonehaven Bay, NE coast of Scotland) from where heart tissues obtained from common dab also tested positive. While no virus could be cultivated from these samples, qPCR detections were shown to be SAV-specific by sequencing of an alternative gene region (E2) to that targeted by the qPCR assay. Analysis of these nucleotide sequences revealed minor differences to those previously obtained from farmed salmon, and subsequent phylogenetic analysis of an E2 dataset demonstrated a subtype V-like sequence.
\end{abstract}

KEY WORDS: Salmonid alphavirus $\cdot$ SAV $\cdot$ Salmon pancreas disease - SPDV - Real-time PCR · Detection · Wild fish

\section{INTRODUCTION}

Salmonid alphaviruses (SAVs) are among the most significant viral pathogens of European salmonid aquaculture and include the aetiological agents of salmon pancreas disease (SPD) in farmed Atlantic salmon Salmo salar L. and sleeping disease (SD) in rainbow trout Oncorhynchus mykiss (Walbaum) (for review see McLoughlin \& Graham 2007). Clinical signs associated with SPD include abnormal swimming behaviour and lack of appetite, while characteristic histopathological signs include severe degeneration of exocrine pancreas, cardiomyopathy and skeletal myopathy (McLoughlin et al. 2002). SD involves similar lesions but often manifests itself as fish lying on their side or 'sleeping' as a consequence of extensive necrosis of skeletal red muscle (Boucher \& Laurencin 1996).

To date, 6 different clades or subtypes of SAV have been recognized based on comparative analysis of nucleotide sequence data derived from the E2 surface glycoprotein and the non-structural protein nsP3 (Fringuelli et al. 2008). Subtype II mostly includes sleeping disease virus (SDV) isolates responsible for disease outbreaks in rainbow trout in continental 
Europe and the UK where it is thought to have been introduced along with import of fish around 2002 (Branson 2002, Weston et al. 2005). Isolates recovered from Atlantic salmon in Scotland have also, however, been classified within this group, which has been interpreted as suggesting a potential marine original of SDV (Fringuelli et al. 2008). Minimum and maximum levels of nucleotide variation between isolates from different subtypes were shown to be 3.4 to $16.2 \%$ and 6.5 to $33.3 \%$ based on partial E2 and nsP3 sequences respectively (Fringuelli et al. 2008).

Subtypes I, III, IV, V and VI include salmon pancreas disease virus (SPDV) isolates, responsible for outbreaks of pancreas disease in farmed salmon, which occur at all stages of the marine production cycle, but which are generally diagnosed in grower fish during their second year at sea (McLoughlin \& Graham 2007). To date, subtypes I, II, IV, V, and VI have been identified within the British Isles (Fringuelli et al. 2008). Norwegian SPD outbreaks, however, appear to be exclusively caused by subtype III isolates, which as yet have not been identified outwith Norway.

The lack of detection of SAV subtype III in the British Isles, coupled to the considerable current and historic import of salmon ova from Norway into this region is indicative that vertical transmission does not play a significant role in the epizootiology of SAV. Indeed, horizontal transmission, which has been experimentally demonstrated (McLoughlin et al. 1996), is thought to be the predominant transmission route, and this is supported by the observation that the virus can survive for considerable time in seawater (Graham et al. 2007).

The fact that Scottish and Irish SAV sequences recovered from marine farmed Atlantic salmon are represented in 5 of the 6 recognised SAV subtypes, while Norwegian SAVs appear exclusively restricted to a single clade, raises interesting questions regarding the origins and spread of SAV. Within the UK, the epidemiology of SAV is difficult to fully understand, in part due to the ubiquity of the pathogen, lack of systematic surveillance and complexities of trade. What is clear is that on occasion, identical sequences at individual farm sites have been recorded over multiple years (Fringuelli et al. 2008). This has been suggested to indicate a slowly evolving virus (Fringuelli et al. 2008), but it also implies the maintenance of a consistent reservoir of infection that may be associated with either environmental or anthropogenic processes. The fact that SPDV tends to recur in successive generations of fish introduced into certain historically infected sites, despite implementation of management practices including fallowing periods, supports the suggestion that reservoirs of infection may exist in the environment (McLoughlin \& Graham 2007). Clearly, whilst a natural source of SAV-like virus might exist, represent- ing an ancestor of the original introductions, it is also plausible that amplification and spread of SAV from infected fish farms may have led to the establishment of potential reservoirs of re-infection.

To date, little focus has been placed on understanding reservoirs of infection for SAVs, an understanding that could contribute to improved management of this important disease. Unlike other alphaviruses which require an arthropod vector to complete their life cycle, SAV is known to transmit from primary host to host (McLoughlin et al. 1996). The aim of the present study was to attempt to identify natural carriers of SAV through the examination of tissues collected from wild marine fish caught from the waters close to marine Atlantic salmon farms in an area with a history of SAV infection, and from a region remote from aquaculture activity using real-time PCR (qPCR).

\section{MATERIALS AND METHODS}

Sample collection in the vicinity of aquaculture activity. Three sea bed locations (Locations 1 to 3 ) within management area 3a southwest Shetland (Anon 2009) were selected for sampling of wild marine fish as illustrated in Fig. 1. These were chosen to include areas close to marine Atlantic salmon farms and to give a wide ground coverage within the management area. Although according to current European fish health legislation (Anon 2006), SAV is not notifiable in the UK, many of the salmon farms in the area were known to be previously infected. Fish were caught from these locations using a demersal trawl in February 2009. The catches were put on ice and transported to a shore based laboratory for sampling. The species $(\mathrm{n}=12)$ and number of individual fish $(\mathrm{n}=1161)$ screened are detailed in Table 1. For each species, fish were pooled as groups of 5 ind., although smaller pools were occasionally taken based on fish availability. For each fish sampled, $3 \mathrm{~mm}^{3}$ of tissue (kidney and heart) was taken using individual sterile scalpels for each tissue type. Single tissue types from each of the fish included in the pool were placed in an individually labelled $1.5 \mathrm{ml}$ tube containing $1 \mathrm{ml}$ RNAlater (Ambion) resulting in 2 separate organ samples per pool of fish. These samples were chilled at $4^{\circ} \mathrm{C}$ for transport to the laboratory and stored at $-80^{\circ} \mathrm{C}$ prior to testing.

Sample collection in an area remote from aquaculture activity. Marine fish were caught by demersal trawl on 2 occasions (24/7/09 and 11/09/09) in the vicinity of Stonehaven Bay, Aberdeenshire, Scotland (Location 4), which represents an area remote from aquaculture activity. The sampling area is indicated in Fig. 1. Fish were transferred to the laboratory where they were maintained live for up to $17 \mathrm{~d}$ in a 


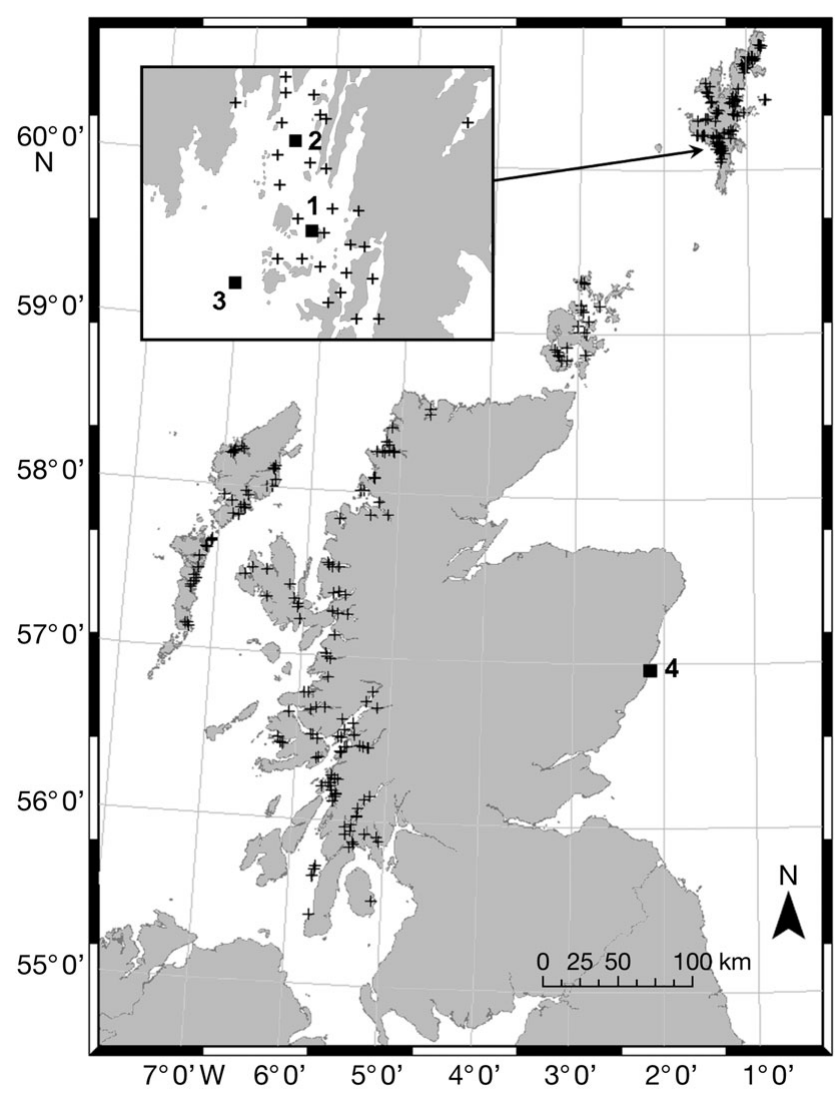

Fig. 1. Scotland and wild fish sampling locations. +: marine salmonid farm distribution in Scotland, $\mathbf{n}$ : locations of SAVpositive wild marine fish caught at Locations 1, 2, 3 (Shetland Isles) and 4 (Stonehaven, NE Scotland). Inset: more specific location of the Shetland salmonid farms and wild fish sampling locations

biosecure aquarium facility that receives natural seawater, which is mechanically filtered and subject to UV irradiation prior to introduction into a recirculation system. This system includes biofiltration, ozone and UV treatment and no salmonid fish or fish disease work is conducted within it. A total of 192 ind. common dab Limanda limanda were sampled as indicated in Table 1. Samples were taken in a similar manner to that described for those taken in the vicinity of aquaculture activity, although tissue (heart only) was sampled and processed from individual fish instead of pools. Parallel samples were obtained for potential tissue culture isolation of virus and consisted of organ pools (kidney and heart) from 5 ind., which were diluted $1: 10$ in viral transport medium (Liebovitz L-15 cell culture media [Lonza], 10\% newborn calf serum [Invitrogen], gentamicin at $50 \mathrm{mg}$ $\mathrm{ml}^{-1}$ [PAA], polymixin 'B' at $10000 \mathrm{U} \mathrm{ml}^{-1}$ [SigmaAldrich] with a final $\mathrm{pH}$ value of 7.4 to 7.8 ). Samples were kept chilled and transferred to the laboratory for storage at $-80^{\circ} \mathrm{C}$ prior to processing.
RNA extraction and real-time RT-PCR (qRT-PCR). RNA extraction was performed from $\sim 5 \mathrm{mg}$ of homogenized tissue using the Qiagen MagAttract M48 RNA Tissue Kit and a Qiagen M48 Biorobot. RNA was eluted in a final volume of $100 \mu \mathrm{l}$ with $7.7 \mu \mathrm{l}$ of the resultant RNA being used for reverse transcription (Taqman Reverse Transcription Reagent Kit, Applied Biosystems) using a random hexamer primer in a reaction volume of $20 \mu \mathrm{l}$ according to the manufacturer's protocol. Amplification was conducted using primers QnsP1 F, QnsP1 R and the probe QnsP1 P (Hodneland \& Endresen 2006), which are generic and designed to amplify across the spectrum of SAV subtypes. qPCR was performed on an ABI Prism 7000 using a $2 \times$ SensiMix PCR master mix (Quantace) and a reaction volume of $20 \mu \mathrm{l}$ including $1 \mu \mathrm{l}$ of cDNA template with the following cycling conditions: 1 cycle of $37^{\circ} \mathrm{C}$ for $10 \mathrm{~min}, 1$ cycle of $95^{\circ} \mathrm{C}$ for $10 \mathrm{~min}$, followed by 45 cycles of $95^{\circ} \mathrm{C}$ for $15 \mathrm{~s}$ and $60^{\circ} \mathrm{C}$ for $1 \mathrm{~min}$. This assay has been validated in our laboratory and accredited to ISO 17025. A positive control was developed and applied to the routine use of the assay according to the principles established by Snow et al. (2009). Potential contamination with this positive control RNA template is detectable based on the routine inclusion of an additional probe with a different fluorescent label that allows specific detection of this template in all wells. Negative controls were also routinely included at the stages of extraction, reverse transcription and qPCR. SAV detection reactions were conducted in triplicate from each sample with positives only being recorded where a $\mathrm{Ct}$ value was generated from each independent reaction. It was not possible to routinely include an endogenous control such as that developed and applied to the routine examination of salmonid tissues $(E L F 1 \alpha)$ (Moore et al. 2005, Snow et al. 2006) since such controls are largely species or family specific. An endogenous control was, however, available and applied to the gadoid samples which included saithe Pollachius virens, whiting Merlangius merlangus, cod Gadus morhua, haddock Melanogrammus aeglefinus, and Norway pout Trisopterus esmarkii. Primers and probes for this assay were designed from the sequence of cod in order to specifically amplify the ELF1 $\alpha$ mRNA and were as follows: CodELFF 5' CCC CTC CAG GAC GTC TAC AAG 3', CodELFR 5' CAC GGC CCA CGG GTA CT 3' and CodELFP 5' FAM-ATC GGC GGT ATT GGA AC-MGB 3'. All primer and probe sets for qPCR were supplied by Applied Biosystems.

Verification of specificity of positive detections. Where a sample had been identified as positive by real-time PCR, conventional PCR was performed to generate material for sequencing and phylogenetic analysis using primers for the partial E2 gene (Fringuelli et al. 2008). PCR was performed using a 
Table 1. Origin of species and tissues assayed for the presence of salmonid alphaviruses by qPCR. Fish sampled in the vicinity of aquaculture (Locations 1-3, see Fig. 1) were sampled and processed as pools of tissue originating from 5 ind. fish. Fish sampled in Location 4 (remote from aquaculture activity) were sampled and processed as individual fish. qPCR was conducted in triplicate with a positive only being considered when all 3 replicates returned a Ct value (in bold). In some cases, $<3$ of the replicate reactions generated a Ct value. Single Ct values: results from a single pool or individual. Blank spaces: samples tested negative. * Sequence obtained from this sample for verification

\begin{tabular}{|c|c|c|c|c|c|c|c|}
\hline $\begin{array}{l}\text { Species } \\
\text { sampled }\end{array}$ & $\begin{array}{c}\text { Date } \\
\text { (d/mo/yr) }\end{array}$ & Location & $\begin{array}{l}\text { Total no. } \\
\text { of fish } \\
\text { sampled }\end{array}$ & $\begin{array}{l}\text { No. of } \\
\text { pools }\end{array}$ & $\underset{\mathrm{Ct}}{\text { Kidney }}$ & $\begin{array}{c}\text { Heart } \\
\mathrm{Ct}\end{array}$ & $\begin{array}{l}\text { Total pools/fish } \\
\text { pools considered } \\
\text { positive (heart, } \\
\text { kidney, or both) }\end{array}$ \\
\hline Saithe & $\begin{array}{l}09 / 02 / 2009 \\
10 / 02 / 2009 \\
11 / 02 / 2009\end{array}$ & $\begin{array}{l}1 \\
2 \\
3\end{array}$ & $\begin{array}{l}30 \\
10 \\
30\end{array}$ & $\begin{array}{l}6 \\
2 \\
6\end{array}$ & & & $\begin{array}{l}0 / 6 \\
0 / 2 \\
0 / 6\end{array}$ \\
\hline Whiting & $\begin{array}{l}09 / 02 / 2009 \\
10 / 02 / 2009 \\
11 / 02 / 2009\end{array}$ & $\begin{array}{l}1 \\
2 \\
3\end{array}$ & $\begin{array}{c}35 \\
140 \\
100\end{array}$ & $\begin{array}{c}7 \\
28 \\
20\end{array}$ & & & $\begin{array}{c}0 / 7 \\
0 / 28 \\
0 / 21\end{array}$ \\
\hline Sculpin sp. & 09/02/2009 & 1 & 70 & 14 & 38.02 & $\begin{array}{c}36.38,36.04 \\
39.92\end{array}$ & $0 / 14$ \\
\hline Cod & $\begin{array}{l}09 / 02 / 2009 \\
11 / 02 / 2009\end{array}$ & $\begin{array}{l}1 \\
3\end{array}$ & $\begin{array}{c}4 \\
25\end{array}$ & $\begin{array}{l}1 \\
5\end{array}$ & & & $\begin{array}{l}0 / 1 \\
0 / 5\end{array}$ \\
\hline Norway pout & $10 / 02 / 2009$ & 2 & 150 & 30 & & & $0 / 30$ \\
\hline Herring & $10-11 / 02 / 2009$ & 2 & 15 & 3 & & & $0 / 3$ \\
\hline Haddock & $11 / 02 / 2009$ & 3 & 30 & 6 & & & $0 / 6$ \\
\hline Argentine & 11/02/2009 & 3 & 15 & 3 & & & $0 / 3$ \\
\hline Flounder & 09/02/2009 & 1 & 2 & 1 & & & $0 / 1$ \\
\hline \multirow[t]{2}{*}{$\begin{array}{l}\text { Long rough } \\
\text { dab }\end{array}$} & $09-10 / 02 / 2009$ & 1 & 150 & 30 & & $\begin{array}{c}\mathbf{3 3 . 8 4 ,}, \mathbf{3 5 . 2 6}, \mathbf{3 8 . 4 1} \\
35.36 \\
\mathbf{3 8 . 0 2 ,} \mathbf{3 7 . 2 5 ,}, \mathbf{3 6 . 0 3} \\
43.87 \\
36.64 \\
37.04,37.00\end{array}$ & $2 / 30$ \\
\hline & $10 / 02 / 2009$ & 2 & 50 & 10 & & & $0 / 10$ \\
\hline Plaice & $09 / 02 / 2009$ & 1 & 55 & 11 & $\begin{array}{c}\mathbf{2 6 . 0 1}^{2} \mathbf{2 6 . 0 1}, \mathbf{2 6 . 0 5}^{*} \\
34.29\end{array}$ & $\begin{array}{c}\mathbf{2 7 . 2 0 , 2 6 . 9 4 , 2 6 . 8 5} \\
38.76,38.88 \\
40.25\end{array}$ & $1 / 11$ \\
\hline \multirow[t]{2}{*}{ Common dab } & $09-10 / 2 / 2009$ & 1 & 100 & 20 & $\begin{array}{c}36.11,37.72 \\
\mathbf{3 5 . 1 1 , 3 5 . 9 4 , 3 6 . 3 5} \\
36.87 \\
38.13 \\
37.04,38.37\end{array}$ & 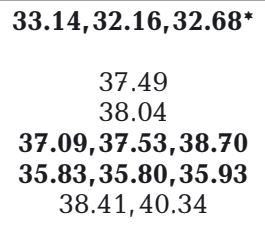 & $4 / 20$ \\
\hline & $10-11 / 02 / 2009$ & 2 & 150 & 30 & $\begin{array}{c}32.02,32.44,32.57^{*} \\
37.55\end{array}$ & 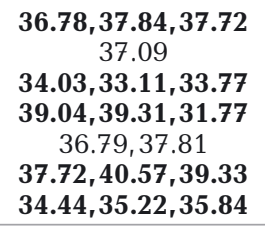 & $5 / 30$ \\
\hline Total & & & 1161 & 233 & & & \\
\hline \multirow[t]{2}{*}{$\begin{array}{l}\text { Location } 4 \\
\text { Common dab }\end{array}$} & 11/08/2009 & 4 & 25 & 25 & Not tested & $33.59,34.00,33.40$ & $1 / 25$ \\
\hline & $21 / 09 / 2009$ & 4 & 167 & 167 & Not tested & $\begin{array}{c}\mathbf{3 2 . 5 7}, \mathbf{3 2 . 1 8}, \mathbf{3 2 . 0 9} \\
\mathbf{3 3 . 1 0}, \mathbf{3 3 . 4 2}, \mathbf{3 3 . 9 1} \\
\mathbf{3 6 . 5 3}, \mathbf{3 5 . 3 1}, \mathbf{3 6 . 5 5} \\
\mathbf{3 3 . 9 1}, \mathbf{3 3 . 6 5}, \mathbf{3 4 . 0 1} \\
\mathbf{3 1 . 8 1}, \mathbf{3 1 . 3 3 , 3 1 . 2 2} \\
33.45 \\
38.57 \\
38.46 \\
39.98 \\
36.93,36.37 \\
38.48,38.44\end{array}$ & $5 / 167$ \\
\hline Total & & & 192 & 192 & & & \\
\hline
\end{tabular}


Flexigene thermocycler (Techne) and the following cycling conditions: $94^{\circ} \mathrm{C}$ for $2 \mathrm{~min}$ followed by 40 cycles of $94^{\circ} \mathrm{C}$ for $20 \mathrm{~s}, 57^{\circ} \mathrm{C}$ for $20 \mathrm{~s}, 72^{\circ}$ for $50 \mathrm{~s}$ with a final elongation step of $72^{\circ} \mathrm{C}$ for $5 \mathrm{~min}$. PCR was conducted in a final volume of $50 \mu$ that contained $1 \times$ PCR buffer (Bioline), $1.5 \mathrm{mM} \mathrm{MgCl}_{2}, 500 \mu \mathrm{M}$ dNTPs, $1 \mu \mathrm{M}$ each of primers E2F and E2R, and $1 \mathrm{U}$ BioTaq (Bioline). PCR products were visualised on a $1.5 \%$ agarose (Invitrogen) gel containing ethidium bromide (Sigma). PCR product was either purified directly using ExoSAP IT (GE Healthcare) or excised from agarose gel and purified using MinElute (Qiagen). Approximately $10 \mathrm{ng}$ of purified product was sequenced in both directions using the same primers used in the amplification reaction. Sequencing was conducted using the GenomeLab DTCS Quick Start kit (Beckman Coulter) and automated CEQ8800 DNA sequencer (Beckman Coulter). Sequences were analysed using Sequencher software (Gene Codes). Specificity of sequences was determined using the Basic Local Alignment Search Tool (BLAST; Altschul et al. 1990). A sequence alignment is detailed in Fig. 2.

Virus culture. Samples from Location 4 corresponding to those yielding positive real-time PCR results were thawed, clarified by centrifugation at $2000 \times g$ for 15 min and inoculated at a 1:100 and 1:1000 dilution onto 12 well plates containing monolayers of CHSE214 cells. The cell monolayers were at a confluency of 60 to $80 \%, 24$ to $48 \mathrm{~h}$ old and incubated at $15^{\circ} \mathrm{C}$ following inoculation. Cultures were read every $7 \mathrm{~d}$ for cytopathic effect (CPE) and subcultivation procedures were carried out on Days 14 and 28. At 28 d, cell monolayers were scraped and RNA harvested from them according to the method previously described. An SAV-specific qPCR was conducted on these samples to test for the presence of SAV RNA.

Molecular epidemiological analysis. Sequences were imported into Bioedit version 7.0.5.3 (Hall 1999) alongside other publically available SAV sequences from a previous study (Fringuelli et al. 2008) and a multiple alignment performed using Clustal X (Larkin et al. 2007). The resultant alignment was manually edited based on amino-acid sequence. Only substitutions were observed with no deletions identified. Identical sequences were identified and only a single representative of each sequence type retained in the dataset to reduce subsequent analytical bias. The final alignment consisted of 36 unique sequences spanning a region of 298 nucleotides of the $\mathrm{E} 2$ gene representing sequence from a total of 83 isolates, which are detailed in Table 2. The phylogenetic relationship among SAV isolates was inferred using a maximum likelihood based approach implemented within PAUP* (version 4.0; Swofford 2000) and using the PaupUP interface v1.0.3.1 (Calendini \& Martin, 2005). The MODELTEST program (Posada \& Crandall 1998) was used to identify the model that best fits the sequence data from 56 models using the Akaike Information Criterion (AIC Akaike 1974). This model selected was $\mathrm{TrN}+\mathrm{G}$ and is defined as: assumed base frequencies $\mathrm{A}=0.2666, \mathrm{C}=$ $0.3014, \mathrm{G}=0.2356, \mathrm{~T}=0.1964$; proportion of invariable sites $=0$; rate matrix $\mathrm{A}-\mathrm{C}=1.0000, \mathrm{~A}-\mathrm{G}=7.2103, \mathrm{~A}-\mathrm{T}=$ $1.0000, \mathrm{C}-\mathrm{G}=1.0000, \mathrm{C}-\mathrm{T}=17.3870, \mathrm{G}-\mathrm{T}=1.0000$; gamma $=0.3149$.

An optimal unrooted maximum likelihood tree (Fig.3) was identified using a heuristic search implemented in PAUP* and evaluated using 100 bootstrap iterations (Felsenstein 1985). Significant bootstrap values for the major clades were transferred to the unrooted tree derived from the original data. Independent maximum likelihood analysis implemented in Paup* also resulted in a similar overall tree topology, supporting the differentiation of the subgroups first reported by Fringuelli et al. (2008).

\section{RESULTS}

\section{qPCR detection}

Positive and negative controls performed as expected in all cases demonstrating that the SAV assay worked in each case with no detectable contamination. Endogenous control data was generated from 113 pools of gadoids sampled from the Shetland area and indicated consistent quality and quantity of RNA extracted. The range of ELF values obtained for all pools was 18.32 to 24.08 with an average value of 21.46 $\pm 0.12(\mathrm{SE})$.

\section{Marine fish sampled in the vicinity of aquaculture activity}

Positive SAV detections were only observed for flatfish species, from which both heart and kidney pools were screened. Positive qPCR results generated in pools of heart or kidney are detailed in Table 1. A sample was only regarded as being truly positive when all of the triplicate $\mathrm{qPCR}$ reactions generated a $\mathrm{Ct}$ value. Cases where $1 / 3$ or $2 / 3 \mathrm{Ct}$ values were generated are also given for discussion. Based on this criterion, 2/30 (6.67\%) pools of long rough dab Hippoglossoides platessoides tested positive for the presence of SAV RNA with only the heart tissues yielding positive results in each case. Other incidences where $1 / 3(n=3)$ or $2 / 3(n=1)$ reactions returned $\mathrm{Ct}$ values were recorded. Both positive samples originated from Location 1. In the case of plaice Pleuronectes platessa, only $1 / 11(9.09 \%)$ samples from 

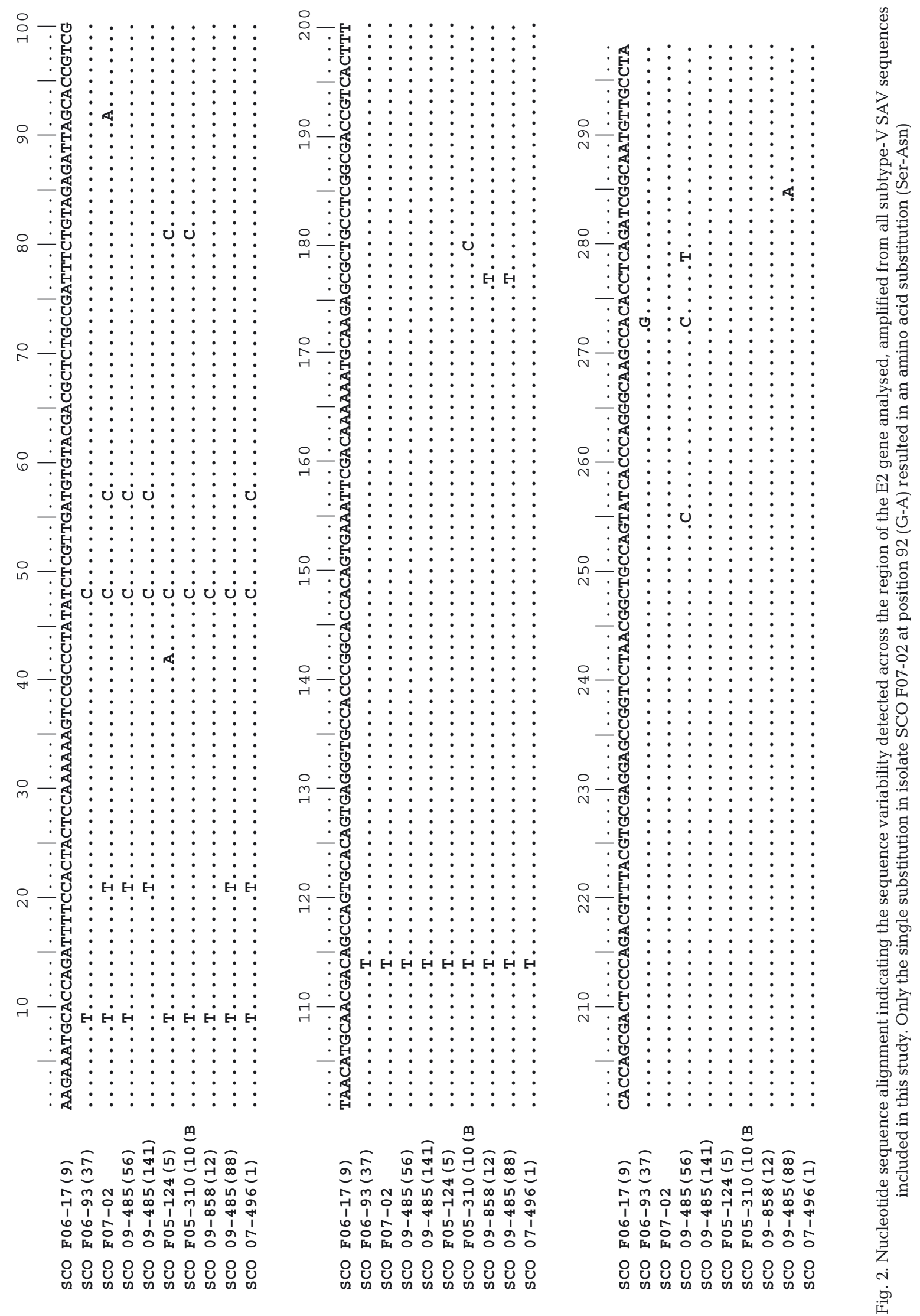

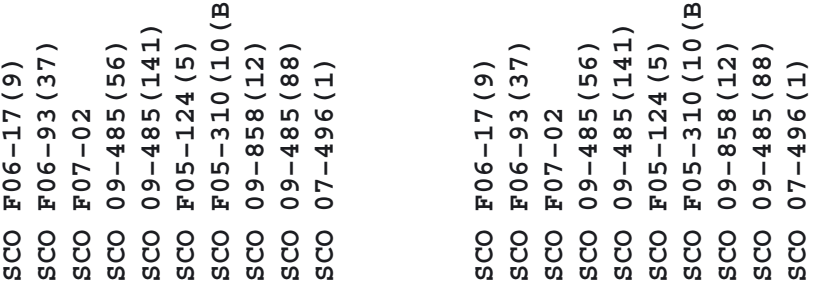


Table 2. Details of the origins of E2 sequences used in this study. Isolates in bold type: unique sequences selected for use in phylogenetic analysis. Isolates following an isolate in bold were identical in sequence. AS = Atlantic salmon, RT= rainbow trout

\begin{tabular}{|c|c|c|c|c|c|c|}
\hline Subtype & Virus & Year & Species & Country & Source & Accession no. \\
\hline \multirow[t]{21}{*}{ I } & IRE-F93-125 & 1993 & AS & Ireland & CHSE-214 cells & AJ316244 \\
\hline & IRE-F03-123 (3) & 2003 & AS & Ireland & Serum & EF675548 \\
\hline & IRE-F05-27 (13) & 2005 & AS & Ireland & Serum & EF675507 \\
\hline & IRE-F04-183 (A1) & 2004 & AS & Ireland & Serum & EF675511 \\
\hline & IRE-F05-238 (9) & 2005 & AS & Ireland & Serum & EF675505 \\
\hline & IRE-F06-227 (20) & 2006 & AS & Ireland & Serum & EF675506 \\
\hline & IRE-F05-294 (3) & 2005 & AS & Ireland & Serum & EF675512 \\
\hline & IRE-F05-118 (5) & 2005 & AS & Ireland & Serum & EF675510 \\
\hline & IRE-F05-190(38) & 2005 & AS & Ireland & Serum & EF675557 \\
\hline & SCO-08-494 (82) & 2008 & AS & Scotland & CHSE-214 cells & \\
\hline & SCO-09-816 (1) & 2009 & AS & Scotland & CHSE-214 cells & \\
\hline & IRE-F02-194 (11) & 2002 & AS & N Ireland & Serum & EF675552 \\
\hline & SCO-09-590 (1) & 2009 & AS & Scotland & Kidney & \\
\hline & SCO 07-920 (3) & 2007 & AS & Scotland & CHSE-214 cells & \\
\hline & SCO-07-765 (1) & 2007 & RT & Scotland & CHSE-214 cells & \\
\hline & SCO-07-887 (1) & 2007 & AS & Scotland & CHSE-214 cells & \\
\hline & IRE-F06-182 (55) & 2006 & AS & Ireland & Serum & EF675549 \\
\hline & IRE-F06-43 (4) & 2006 & AS & Ireland & Serum & EF675556 \\
\hline & IRE-F05-184 (5) & 2005 & AS & Ireland & Serum & EF675550 \\
\hline & IRE-F2111(1) & 2002 & AS & Ireland & Serum & EF675503 \\
\hline & SCO-09-864 (1) & 2009 & AS & Scotland & Kidney & \\
\hline \multirow[t]{28}{*}{ II } & SCO 07-501 (1) & 2007 & AS & Scotland & Kidney & \\
\hline & FR-EE37 & & RT & France & Heart & EF675578 \\
\hline & IT-F04-198(22D) & 2004 & RT & Italy & Serum & EF675590 \\
\hline & IT-F04-198(29D) & 2004 & $\mathrm{RT}$ & Italy & Serum & EF675588 \\
\hline & IT-F05-105(12) & 2005 & RT & Italy & Serum & EF675589 \\
\hline & SPA-F04-08(18)C & 2004 & RT & Spain & Serum & EF675587 \\
\hline & SPA-F04-08(6)C & 2004 & RT & Spain & Serum & EF675586 \\
\hline & FR-S49P & 1995 & RT & France & CHSE-214 cells & AJ316246 \\
\hline & FR-VF03(p4) & 2002 & RT & France & CHSE-214 cells & EF675579 \\
\hline & SCO-07-292 (1) & 2007 & RT & Scotland & Kidney & \\
\hline & SCO 02-798 (1) & 2002 & RT & Scotland & Kidney & \\
\hline & SCO 02-966 (5) & 2002 & RT & Scotland & CHSE-214 cells & \\
\hline & SCO 03-1203 (1) & 2003 & AS & Scotland & CHSE-214 cells & \\
\hline & SCO 06-396 (2) & 2006 & RT & Scotland & CHSE-214 cells & \\
\hline & SCO-F02-85(9) & 2002 & $\mathrm{RT}$ & Scotland & CHSE-214 cells & EF675580 \\
\hline & SCO-07-200 (15) & 2007 & RT & Scotland & CHSE-214 cells & \\
\hline & SCO-07-110 (1) & 2007 & RT & Scotland & Kidney & \\
\hline & ENG-F04-212(5) & 2004 & RT & England & Serum & EF675585 \\
\hline & ENG-F02-67(18) & 2002 & RT & England & Serum & EF675584 \\
\hline & SCO-F06-119(7) & 2006 & RT & Scotland & Serum & EF675581 \\
\hline & SCO 09-269 (1) & 2009 & AS & Scotland & Kidney & \\
\hline & P42Pdnar & 2000 & AS & Scotland & CHSE-214 cells & \\
\hline & SCO-03-1201 & 2003 & AS & Scotland & CHSE-214 cells & \\
\hline & SCO-F06-290(6)A & 2006 & AS & Scotland & Serum & EF675582 \\
\hline & SCO-F06-290(8)A & 2006 & AS & Scotland & Serum & EF675583 \\
\hline & SCO-07-376 (1) & 2007 & AS & Scotland & Kidney & \\
\hline & SCO-08-312 (20) & 2008 & AS & Scotland & Kidney & \\
\hline & SCO-09-958 (1) & 2009 & AS & Scotland & Kidney & \\
\hline \multirow[t]{8}{*}{ III } & NO-SavH20/03 & 2003 & & Norway & Heart/Kidney & AY604235 \\
\hline & NO-SavH10/02 & 2002 & & Norway & CHSE-214 cells & AY604236 \\
\hline & NO-PD97-N3 & 1997 & & Norway & CHSE-214 cells & AY604237 \\
\hline & NO-SavSF21/03 & 2003 & AS & Norway & Heart/Kidney & AY604238 \\
\hline & NO-F04-170(6)E & 2004 & AS & Norway & Serum & EF675591 \\
\hline & NO-F04-170(8)E & 2004 & AS & Norway & Serum & EF675592 \\
\hline & NO-F04-170(3)E & 2004 & AS & Norway & Serum & EF675593 \\
\hline & NO-F04-170(7)E & 2004 & AS & Norway & Serum & EF675594 \\
\hline \multirow[t]{2}{*}{ IV } & SCO-F06-139(33) & 2006 & & Scotland & Serum & EF675569 \\
\hline & IRE-F91-116(p1-6) & 1991 & AS & Ireland & Serum & EF675564 \\
\hline
\end{tabular}


Table 2 (continued)

\begin{tabular}{|c|c|c|c|c|c|c|}
\hline Subtype & Virus & Year & Species & Country & Source & Accession no. \\
\hline & IRE-F91-115(A3) & 1991 & $\mathrm{AS}$ & Ireland & Serum & EF675563 \\
\hline & SCO-F06-243(4) & 2006 & AS & Scotland & Serum & EF675566 \\
\hline & SCO-F03-209(3) & 2003 & AS & Scotland & Serum & EF675565 \\
\hline & IRE-F04-44(10) & 2004 & AS & Ireland & Serum & EF675560 \\
\hline & IRE-F06-186(5) & 2006 & AS & Ireland & Serum & EF675561 \\
\hline & SCO-07-256 (4) & 2007 & $\mathrm{AS}$ & Scotland & Kidney & \\
\hline \multirow[t]{17}{*}{$\mathrm{V}$} & SC0-F06-17(9) & 2006 & $\mathbf{A S}$ & Scotland & Serum & EF675568 \\
\hline & SCO-F06-93(37) & 2006 & $\mathbf{A S}$ & Scotland & Serum & EF675567 \\
\hline & SCO-F06-241(1) & 2006 & AS & Scotland & Serum & EF675572 \\
\hline & SCO-F06-41(54) & 2006 & AS & Scotland & Serum & EF675570 \\
\hline & SCO-07-496 (1) & 2007 & AS & Scotland & Cells & \\
\hline & SCO-F07-02 & 2007 & AS & Scotland & Serum & EF675571 \\
\hline & SCO-09-485a (56) & 2009 & Dab & Scotland & Heart & \\
\hline & SCO-09-485c (141) & 2009 & Dab & Scotland & Kidney & \\
\hline & SCO-F05-124(5) & 2005 & AS & Scotland & Serum & EF675577 \\
\hline & SCO-F06-267(9) & 2006 & AS & Scotland & Serum & EF675574 \\
\hline & SCO-F04-224(17) & 2004 & $\mathrm{AS}$ & Scotland & Serum & EF675573 \\
\hline & SCO-F05-310(10)B & 2005 & $\mathbf{A S}$ & Scotland & Serum & EF675575 \\
\hline & SCO-F05-310(18)B & 2005 & AS & Scotland & Serum & EF675576 \\
\hline & SCO-09-858 (12) & 2009 & Dab & Scotland & Heart & \\
\hline & SCO-09-913a (8) & 2009 & Dab & Scotland & Heart & \\
\hline & SCO-09-913b (125) & 2009 & Dab & Scotland & Heart & \\
\hline & SCO-09-485b (88) & 2009 & Plaice & Scotland & Kidney & \\
\hline VI & IRE-F1045/96 & 1996 & $\mathbf{A S}$ & Ireland & CHSE-214 cells & EF675547 \\
\hline
\end{tabular}

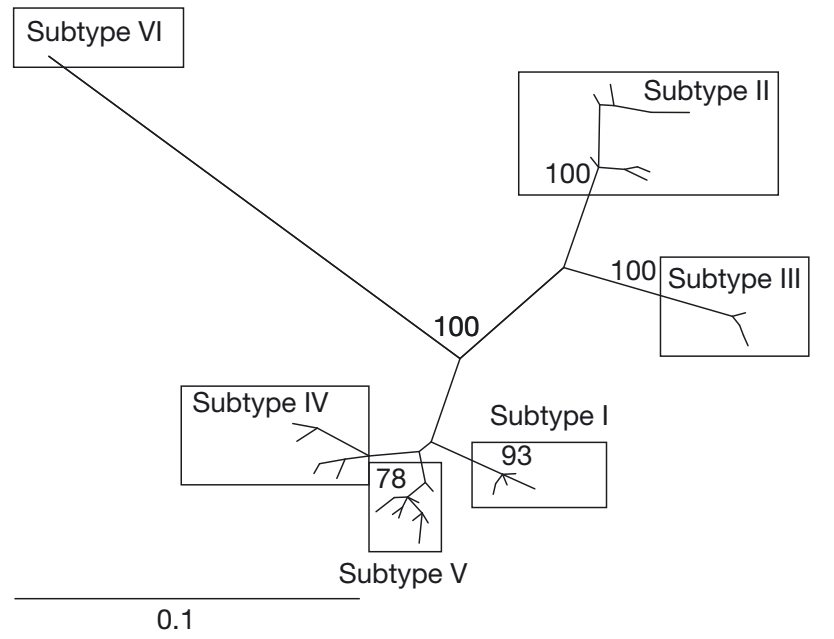

Fig. 3. Inferred genetic relationships between detected sequences of a region of the E2 gene of salmonid alphaviruses. Phylogram was generated from a sequence alignment of all available E2 sequences corresponding to a region spanning positions 8928-10241 with respect to characterized isolate F93-125 (AJ316244). Duplicate sequences were excluded. Modeltest was used to identify the best model fitting the data, and the optimum maximum likelihood tree identified using the heuristic search option as implemented in Paup*. Confidence in tree topology was assessed using 100 bootstrap iterations and a maxiumum likelihood/heuristic search approach. Boostrap values $>75$ were transferred to the original maximum likelihood tree derived from the original data. Scale bar: number of substitutions per nucleotide site
Location 1 tested positive although again some pools resulted in $\mathrm{Ct}$ values in $<3$ replicate reactions. The positive sample from plaice yielded the lowest $\mathrm{Ct}$ values of all those tested, and both kidney and heart pool tested positive. Finally 9/50 pools $(18.00 \%)$ of common dab tested positive in either kidney or heart pool. Generally more heart pools tested positive ( $\mathrm{n}=$ 8) than kidney $(n=2)$, although a single sample was positive for kidney yet negative for heart. Based on these results, only heart tissues were screened for the remaining marine fish species sampled, and all tested negative for SAV.

\section{Marine fish sampled in an area remote from aquaculture activity}

Due to the relatively high SAV positive detection frequency in common dab identified above and their local availability, this species was targeted for screening for the presence of SAV in the area remote from aquaculture activity. Positive pools or individuals were obtained on 2 independent sampling trips with $1 / 25$ $(4.00 \%)$ and $5 / 167(2.99 \%)$ individual fish testing positive respectively. All kidneys originating from the first 25 fish sampled tested negative, while only heart samples were processed from the second sampling of 167 ind. 


\section{Verification of the specificity of qPCR detections}

Sequence data was obtained by amplification of a region of the E2 gene that is independent from the region of the genome targeted by the qPCR primers and probe (nsP1). Sequencing from all positives was attempted, but due to the generally high $\mathrm{Ct}$ values, it was only possible from the samples indicated in Table 1. Thus, SAV-specific sequence was obtained from a total of 6/17 of the total number of pools (either heart or kidney) testing positive. Analysis of this sequence data indicated that the sequences were similar, though none were identical to those derived from subtype V first identified by Fringuelli et al. (2008). As detailed in Table 1 and Fig. 2, 4 unique sequences were obtained among those from wild fish, with none of the substitutions leading to changes at the amino acid level.

\section{Virus culture}

No virus isolate was obtained following inoculation of cell cultures with homogenates derived from any tissues from individuals (Stonehaven samples) that tested positive for SAV by qPCR. Screening of cultures using qPCR did not indicate evidence of SAV amplification.

\section{Molecular epidemiological analysis}

As expected the 6 major SAV subtypes identified by Fringuelli et al. (2008) were readily identifiable and supported by high bootstrap values (Fig. 3). All wild fish sequences obtained in the present study were classified within subtype $\mathrm{V}$ on this basis. Interestingly only a single sequence type was identified in the wild fish sequences obtained from the area remote from aquaculture (Stonehaven), although 3 different variable sequences were obtained from the area in the vicinity of aquaculture activity (Shetland). Although bootstrap values were not significant at this level, it is interesting that one of the Shetland sequences clustered with those from Stonehaven whilst the remaining Shetland sequences clustered with other aquaculture derived isolates from Scotland in 2007 (SCO-F07-02 and SCO-07-0496).

\section{DISCUSSION}

This report constitutes the first detection of SAV genome in wild-caught non-salmonid marine fish species. While tissue culture virus isolation was attempted from parallel samples corresponding to those testing
qPCR positive, no viral isolates were obtained. This negative result is perhaps not surprising given the relatively high $\mathrm{Ct}$ values which are indicative of a low level of viral RNA presence in the samples.

Interestingly, while little is known about SAV infection of non-salmonids or of the kinetics of infection with SAV isolates of differing subtype, the PCR-based detection of prolonged persistence of viral RNA in tissues of farmed Atlantic salmon from which virus could not be isolated has been previously reported (Christie et al. 2007, Graham et al. 2010). An added challenge to virus isolation is the possibility that initial isolation of new variants of SAV can be difficult due to a suggested degree of cell-culture selection or adaptation (McLoughlin \& Graham 2007).

The lack of supporting evidence from other diagnostic methods necessitates caution in interpreting results obtained solely on the basis of qPCR studies especially given the potential for reporting false findings. Supporting the validity of the reported results in the present study is the fact that the qPCR assay employed has been previously demonstrated to be very sensitive for SAV detection (see Graham et al. 2010) and has been accredited to ISO 17025 in our laboratory. Part of this accreditation has been the decision to conduct qPCR reactions in triplicate. Experience with $\mathrm{qPCR}$ as in diagnostic assays in general has indicated that results can be difficult to reproduce when approaching the limit of detection for any assay (high Ct values). Conducting an assay in triplicate, while perhaps potentially leading to the under-reporting of the true level of positivity, gives increased confidence in the reporting of results especially when approaching an assays limit of detection. Furthermore, it greatly reduces the chance of sporadic laboratory contamination leading to the generation of an individual false-positive PCR result. The use of an artificial control RNA template which is routinely distinguishable from sample positives based on a previously established principle (Snow et al. 2009) also gives confidence that the SAV positives obtained did not result from use of a positive control template. Adding to the confidence that real detections are reported here is the reported subsequent verification of positive qPCR signals based on sequencing of a region of a gene different to that targeted by the Taqman PCR primers and probe. The fact that the sequences identified were unique and not identical to any known agent previously handled in this laboratory further strongly supports the specificity of the reported SAV RNA detections.

Based on this evidence, there seems little to question the reporting of the specific detection of SAV RNA in Locations 1 to 3 associated with fish farming activity. One might argue, however, that since fish sampled from Location 4 were held briefly in a holding facility, 
infection may have originated from this source. This is very unlikely based on the following evidence: (1) the independent demonstration of positive detections in common dab from other areas, (2) no disease work is undertaken in this facility, (3) appropriate biosecurity measures are in place and (4) no salmonids or other known SAV hosts are maintained in this system. Furthermore, the source of water originates from a location close to Location 4, suggesting that if the fish were infected via this route, then they would likely have been naturally exposed to virus in these waters.

The level of positive detections was relatively high in common dab within the Shetland area, which is a species that has a wide geographic distribution and abundance throughout the North Sea and is hence incorporated into pollution and fish health monitoring programmes using externally visible diseases (Vethaak \& Rheinallt 1992). Indeed, it is the most abundant flatfish in the North Sea with an estimated biomass of 2 million tonnes (Sparholt 1990, Daan et al. 1990). The population structure and migration habits of common dab are unclear despite numerous studies (for review see Rijnsdorp et al. 1992). Available data does, however, suggest a predominant seasonal migration from inshore feeding areas to offshore spawning grounds (Rijnsdorp et al. 1992). Other species tested, some of which potentially undertake more significant migration than common dab, tested negative although numbers of individual fish species sampled were too low to rule them out entirely as potential carriers of SAV RNA.

Whist convincing evidence may exist to indicate the specific detection of SAV RNA in this study, it's lack of supporting virus isolation, which is considered the 'gold standard' for demonstrating an active infection with replication-competent virus, makes biological interpretation of the findings difficult. Since the qPCR assay can only report the detection of SAV RNA, further work is required to establish whether viral replication is occurring and if so what biological effect this may have on the host species and its potential to further transmit infection. Interestingly, the persistence of SAV RNA has previously been reported in heart tissues of Atlantic salmon based on experimental data (Christie et al. 2007). Similarly, it was unclear to the authors whether such detections reflected the identification of true carriers capable of virus maintenance and transmission, persistently infected individuals that were epidemiologically insignificant, or individuals in which only RNA from a prior cleared infection was present.

Regardless of the current SAV infection status of the fish examined within this study, it seems reasonable to conclude that detection of SAV RNA is indicative of, at the very least, previous exposure to the virus. Further- more, it is not inconceivable that fish species living in the vicinity of aquaculture activity may have come into contact with a virus that is widely present in the Atlantic salmon industry and is known to transmit horizontally through the water column via shedding from infected fish (McLoughlin et al. 1996). The demonstration that wild fish detections were classified within subtype V, which includes Scottish SAV that has previously been isolated from Atlantic salmon farms, certainly does not preclude this possibility. However, the finding of positive SAV detections within the same species sampled in an area remote from aquaculture clearly questions the significance of such a route of transmission.

Indeed the detection of SAV RNA positive individuals in an area remote from aquaculture activity is difficult to explain. Given the uncertainty surrounding common dab migratory habits, it is not impossible that these fish may have come into contact with SAV derived from fish farms either directly or via an intermediate host, though this scenario seems unlikely. This leads to the possibility that such detections are representatives of natural marine carriers of virus that might have been expected to exist prior to the large scale development of aquaculture. It is interesting to note that such reservoirs have been detected for other significant aquaculture pathogens of salmonids for which similar conclusions have been drawn. For example, in the case of viral haemorrhagic septicaemia virus (VHSV), a widespread and global marine reservoir has been demonstrated, which likely represents the source of virus into the rainbow trout industry (Einer-Jensen et al. 2004, Snow et al. 2004). In this case, considerable evidence for the presence of replication-competent virus has been generated in wild fish, with hundreds of isolations having been made from wild fish that are asymptomatic (Mortensen et al. 1999, King et al. 2001). Viruses of wild origin do not readily infect rainbow trout (Skall et al. 2004) although it seems that a number of adaptation events associated with the selective pressures of intensive aquaculture have led to dramatic changes in virulence properties for this species. Change in viral life strategy is likely related to the change in availability of potential hosts within aquaculture. In wild fish, viruses may have co-evolved with their hosts for millennia with co-evolution leading to a more chronic state of infection where an endpoint of killing ones host likely represents an evolutionary dead-end. While such precedents exist, it is premature to conclude that such a scenario exists for SAV. Fringuelli et al. (2008) also concluded that the monophyletic nature of SAV subtype II was indicative of a single source of introduction of SAV into rainbow trout which could have come from the marine environment. While this may have been from infected Atlantic 
salmon, the original origin of infection in this species is unclear and may be from wild marine fish as appears to be the case for VHSV.

The partial E2 sequences originating from flatfish species reported in this study were similar to viruses currently in circulation within salmonid aquaculture. If these sequences represent that of a true ancestral virus, it is clear that the emergence of subtype V-like isolates in aquaculture must have been a relatively recent event and/or that SAV has a low rate of genetic evolution. Interestingly, the fact that identical sequences at individual farm sites have been recorded over multiple years has been used to suggest a relatively slowly evolving virus (Fringuelli et al. 2008) with substitution rates in the order of $1.7( \pm 1.03) \times 10^{-4} \mathrm{nt}$ $\mathrm{yr}^{-1}$ (Karlsen et al. 2006, Fringuelli et al. 2008).

Subtypes I, IV and V are more similar to each other than to subtype III, which is to be expected given the close geographic proximity of Ireland and Scotland. The identification of subtype is somewhat arbitrary and based on a limited degree of genetic variation. Whilst this study supports the identification of reproducible genetic groups as previously reported (Fringuelli et al. 2008), based on the presented radial phylogram, one could argue for discrimination at the level of a Norwegian subtype (subtype III), a British Isles subtype (I, IV, V) and a predominantly freshwater subtype (II). If subtype discrimination were to be used as basis for management or discrimination of groups of pathogens for determining association with biological properties, it is important that such groupings are robust and reproducible.

The demonstration of multiple subtypes of SAV infecting Atlantic salmon raises interesting questions as to the potential origins of this virus. The apparent low rate of molecular evolution and apparent high divergence between subgroups raises the possibility that introduction of SAV into farmed Atlantic salmon may have occurred on multiple independent occasions. Until a better understanding of the rates of molecular evolution and the degree of genetic diversity in wild populations, this must remain speculation. If this were the case, however, the origins of these inputs might be present in wild fish as has been shown for other significant viral diseases including viral haemorrhagic septicaemia (VHS) (Snow et al. 2004). Since evidence has been presented for the existence of subtype$\mathrm{V}$ like sequences in wild fish, it may be that subtype III sequences may also be represented in the original source of viral introduction into Norwegian aquaculture. This source could be local wild fish in the area of Southern Norway where SPD appears to have emerged or possibly in the Baltic Sea. Indeed, due to the relative isolation of the Baltic Sea and consequent reduction in gene flow, other naturally occurring pathogens including VHSV have been shown to be genetically distinct in this region (Snow et al. 2004).

The lack of knowledge of potential vectors for SAV has been recently highlighted as a gap in current knowledge, better understanding of which would greatly enhance our understanding of the natural history and the control of salmonid pancreas disease (McLoughlin \& Graham 2007). The present study is the first to address this issue and presents the first evidence for the PCR-based detection of SAV RNA in wild marine flatfish species caught both in the vicinity of and in an area remote from aquaculture activity. This information was based on the implementation of a demonstrated and robust assay and supported by subsequent sequence analysis. These results raise many wider questions as to the significance of these findings and provide a basis for further work aimed at better understanding the origins of SAV infection in farms and the role of wild fish. The most important of these is whether these detections reflect the presence of viable virus with the potential to infect salmonids, and whether such viruses can directly cause disease in salmonid farms or must undergo some sort of adaptation.

Acknowledgements. The authors thank the Virology group at Marine Scotland for their technical expertise and input, and M. Hall for his critical evaluation of the manuscript.

\section{LITERATURE CITED}

Akaike H (1974) A new look at statistical model identification. IEEE (Inst Electr Electron Eng). Trans Automatic Control 19:716-723

Altschul SF, Gish W, Miller W, Myers EW, Lipman DJ (1990) Basic local alignment search tool. J Mol Biol 215:403-410 Anon (2006) Council Directive 2006/88/EC of 24 October 2006. Official Journal of the European Union L 328:14-56

Anon (2009) Management area maps June 2009. Marine Scotland Marine Laboratory, Aberdeen, available at: www.scotland.gov.uk/Resource/Doc/295194/0101116.pdf

> Boucher P, Laurencin FB (1996) Sleeping disease and pancreas disease: comparative histopathology and acquired cross-protection. J Fish Dis 19:303-310

Branson EJ (2002) Sleeping disease in trout. Vet Rec 150: $759-760$

Calendini F, Martin J-F (2005) PaupUP v1.0.3.1: a free graphical frontend for Paup* Dos software. www. agro-montpellier.fr/sppe/Recherche/JFM/PaupUp/

Christie KE, Graham DA, McLoughlin MF, Villoing S, Todd D, Knappskog D (2007) Experimental infection of Atlantic salmon Salmo salar pre-smolts by i.p. injection with new Irish and Norwegian salmonid alphavirus (SAV) isolates: a comparative study. Dis Aquat Org 75:13-22

> Daan N, Bromley PJ, Hislop JRG, Nielsen NA (1990) Ecology of North Sea fishes. Neth J Sea Res 26:343-386

> Einer-Jensen K, Ahrens P, Forsberg R, Lorenzen N (2004) Evolution of the fish rhabdovirus viral haemorrhagic septicaemia virus. J Gen Virol 85:1167-1179

$>$ Felsenstein J (1985) Confidence limits on phylogenies: an approach using the bootstrap. Evolution 39:783-791 
Fringuelli E, Rowley HM, Wilson JC, Hunter R, Rodger H, Graham DA (2008) Phylogenetic analyses and molecular epidemiology of European salmonid alphaviruses (SAV) based on partial E2 and nsP3 gene nucleotide sequences. J Fish Dis 31:811-823

Graham DA, Staples C, Wilson CJ, Jewhurst H, Cherry K, Gordon A, Rowley HM (2007) Biophysical properties of salmonid alphaviruses: influence of temperature and $\mathrm{pH}$ on virus survival. J Fish Dis 30:533-543

Graham DA, Fringuelli E, Wilson C, Rowley HM and others (2010) Prospective longitudinal studies of salmonid alphavirus infections on two Atlantic salmon farms in Ireland; evidence for viral persistence. J Fish Dis 33: 123-135

Hall TA (1999) BioEdit: a user-friendly biological sequence alignment editor and analysis program for Windows 95/98/NT. Nucl Acids Symp Ser 41:95-98

> Hodneland K, Endresen C (2006) Sensitive and specific detection of Salmonid alphavirus using real-time PCR (TaqMan). J Virol Methods 131:184-192

Karlsen M, Hodneland K, Endresen C, Nylund A (2006) Genetic stability within the Norwegian subtype of salmonid alphavirus (family Togaviridae). Arch Virol 151:861-874

King JA, Snow M, Smail DA, Raynard RS (2001) Distribution of viral haemorrhagic septicaemia virus in wild fish species of the North Sea, north east Atlantic Ocean and Irish Sea. Dis Aquat Org 47:81-86

Larkin MA, Blackshields G, Brown NP, Chenna R and others (2007) Clustal W and Clustal X version 2.0. Bioinformatics 23:2947-2948

McLoughlin MF, Graham DA (2007) Alphavirus infections in salmonids - a review. J Fish Dis 30:511-531

McLoughlin MF, Nelson RT, Rowley HM, Cox DI, Grant AN (1996) Experimental pancreas disease virus in Atlantic Salmon Salmo salar post-smolts induced by salmon pancreas disease virus (SPDV). Dis Aquat Org 26:117-124

McLoughlin MF, Nelson RN, McCormick JI, Rowley HM, Bryson DB (2002) Clinical and histopathological features of naturally occurring pancreas disease in farmed Atlantic salmon, Salmo salar L. J Fish Dis 25:33-43

Moore LJ, Somamoto T, Lie KK, Dijkstra JM, Hordvik I (2005) Characterisation of salmon and trout CD8alpha and CD8beta. Mol Immunol 42:1225-1234

Editorial responsibility: Mark Crane, Geelong, Victoria, Australia
Mortensen HF, Heuer OE, Lorenzen N, Otte L, Olesen NJ (1999) Isolation of viral haemorrhagic septicaemia virus (VHSV) from wild marine fish species in the Baltic sea, Kattegat, Skagerrak and the North Sea. Virus Res 63: 95-106

Posada D, Crandall KA (1998) Modeltest: testing the model of DNA substitution. Bioinformatics 14:817-818

Rijnsdorp AD, Vethaak AD, van Leeuwen PI (1992) Population biology of dab Limanda limanda in the southeastern North Sea. Mar Ecol Prog Ser 91:19-35

Skall HF, Slierendrecht WJ, King JA, Olesen NJ (2004) Experimental infection of rainbow trout Oncorhynchus mykiss with viral haemorrhagic septicaemia virus isolates from European marine and farmed fishes. Dis Aquat Org 58: 99-110

Snow M, Bain N, Black J, Taupin V and others (2004) Genetic population structure of marine viral haemorrhagic septicaemia virus (VHSV). Dis Aquat Org 61:11-21

Snow M, McKay P, McBeath AJA, Black J and others (2006) Development, application and validation of a Taqman real-time RT-PCR assay for the detection of infectious salmon anaemia virus (ISAV) in Atlantic salmon (Salmo salar). In: Vannier P, Espeseth D (eds) New diagnostic technology: applications in animal health and biologics controls, Vol 126. Dev Biol. Karger, Basel, p 133-145

> Snow M, Mackay P, Matejusova I (2009) Development of a widely applicable positive control strategy for the detection of infectious salmon anaemia virus (ISAV) using Taqman real-time PCR. J Fish Dis 32:151-156

Sparholt H (1990) An estimate of the total biomass of fish in the North Sea. ICES J Mar Sci 46:200-210

Swofford DL (2000) PAUP*. Phylogenetic analysis using parsimony ( ${ }^{*}$ and other methods). Version 4. Sinauer Associates, Sunderland, MA

> Vethaak AD, ap Rheinallt T (1992) Fish disease as a monitor for marine pollution: the case of the North Sea. Rev Fish Biol Fish 2:1-32

> Weston JH, Graham DA, Branson E, Rowley HM, Walker IW, Jewhurst HL, Todd D (2005) Nucleotide sequence variation in salmonid alphaviruses from outbreaks of salmon pancreas disease and sleeping disease. Dis Aquat Org 66: 105-111

Submitted: May 6, 2010; Accepted: July 5, 2010

Proofs received from author(s): September 8, 2010 